\title{
Teaching Introductory American Politics as Part of a Learning Community
}

\author{
Arthur Sanders, Drake University
}

$D_{1}$ uring the fall of 1998 , I took part in an experimental learning community involving my introduction to American politics class, "The American Political System"

(POLS001). Robert Hariman, professor of rhetoric and mass communication, and Ronald Troyer, dean of the College of Arts and Sciences, also participated. We judged it to be a success and we repeated it in the fall of 1999. In this article I report on that experiment, detailing what went well with it and what did not, and also make some observations about how what I learned while participating in this experiment might help me better design and conduct more "typical" introductory American politics classes.

Calls for improving undergraduate education by creating "learning communities" have been common since the early 1990 s. ${ }^{1}$ This phrase seems to mean something different to everyone who discusses it, but the common goal of learning community organizers is to bring students together in ways that will broaden their educational experience and make their classes more than a series of requirements they meet on their way to a degree.

The literature on learning communities is growing rapidly, as are attempts to create them. Researchers with experience in learning communities have argued that such programs can help with retention, meet general education objectives, foster student success, and bring coherence to student class schedules (Matthews

Arthur Sanders teaches courses on American government and politics with a focus on citizen involvement, public opinion, and elections as an associate profess at Drake University. His publications include Making Sense of Politics (lowa State University Press, 1990) and Victory: How a Progressive Democratic Parly Can Win and Govern (M.E. Sharpe, 1992). He is currently researching how television and the Internet are changing American politics. et al. 1996). Our goal was to create an environment where "students and teachers experience courses as a complementary, connected whole, not as arbitrary or isolated offerings" (6).

In a thriving learning community, learning is valued for its own sake and participants are encouraged to make and rewarded for making personal connections deeper than those that usually form among "teachers" and "classmates." Community members will fully engage course materials and concepts in and out of class and will begin to see broader connections between what they learn in specific courses.

Setting up such a learning community requires getting a group of students and faculty to commit to focusing on a common theme and devote themselves to fully exploring it. Although we knew it might not be easy, we set out to confirm findings that "rich rigorous learning environments, active participation on the part of students and faculty members, and a sense of community make a positive and often profound difference in fostering student success" (4). ${ }^{3}$ When the semester was complete, we felt that our learning community had been such a positive learning environment.

\section{Setting Up the Learning Community}

Students in the learning community were enrolled in my section of POLS001 and one of two sections of a first-year seminar (FYS) offered by Professor Hariman and Dean Troyer titled "Perspectives on American Character and Society." In the seminar, students read Tocqueville's Democracy in America (1990) and Bellah et al.'s Habits of the Heart (1985) and explored issues of equality, individualism, and community in American society.
With the help of the staff of Drake's honors program, who also provided some funding for community activities, we recruited 36 incoming first-year students for the community. Although community membership was not restricted to honors students, the bulk of the students involved were in the honors program.

The housing office agreed to set aside part of a single hall of firstyear student housing for members of our community and, unless they had some compelling reason to excuse themselves, all of the students in the community were required to live together on this hall.

We established the community because linked courses and group living could help us realize two objectives. First, we wanted students to explore the issue of individualism, equality, and community in America. In the seminar, students would explore the tensions created by attempts to secure these values in a broad social context. In my POLS001 class, students would focus on how America's political system succeeds or fails in fostering these values. We hoped that the students would make connections among the readings and discussions in both of their classes.

Second, we wanted students to end the semester with more than "book learning." The students would live and work together. They would take two classes in which they would treat issues of community. They would have money to spend as a group. They would, in short, create their own community. To help them do this, we scheduled a series of "town meetings" during which they could discuss how to spend the money the honors program had donated for community activities and any other issues of interest to the group. We hoped that as these 36 students interacted with each other they would reflect on the themes 
discussed in class and, thereby, develop a deeper understanding of community in their lives, at the university, and in the nation.

\section{Course Structure and Requirements}

The two sections of the FYS shared a common syllabus and met at the same time in different rooms. In addition to Tocqueville and Bellah, students read Home from Nowhere: Remaking Our Everyday World for the 21st Century by James Kunstler (1996) and each student wrote four papers over the course of the semester. The class I taught was still, first and foremost, an introductory American politics class. I therefore selected some readings and assignments that would help students conceptualize our political system as an attempt to build a national community of some kind, but never strayed too far from the material most instructors expect students to look at in a basic American politics class. Since I never use a general textbook in the class in any case, I did not find the task of balancing the syllabus too difficult.
I assigned five books for the class, three of which I might have assigned anyway. I chose the other two specifically with the learning community in mind. The first book was a "debate reader," something I always use to provide students with contrasting views of issues in contemporary politics. This time, I chose Herbert Levine's PointCounterpoint (1998). The second and third books focused on the media and Congress, respectively. I usually have books on these institutions-though I sometimes substitute a book on the presidency for the Congress text-and I have the students write essays referencing these books. This time, students read Paul Mongerson's The Power Press (1997) and Robert Dewhirst's Rites of Passage (1997). I chose the fourth and fifth books with the learning community in mind: William Hudson's American Democracy in Peril (1998), a critical look at the way our governmental system oper-

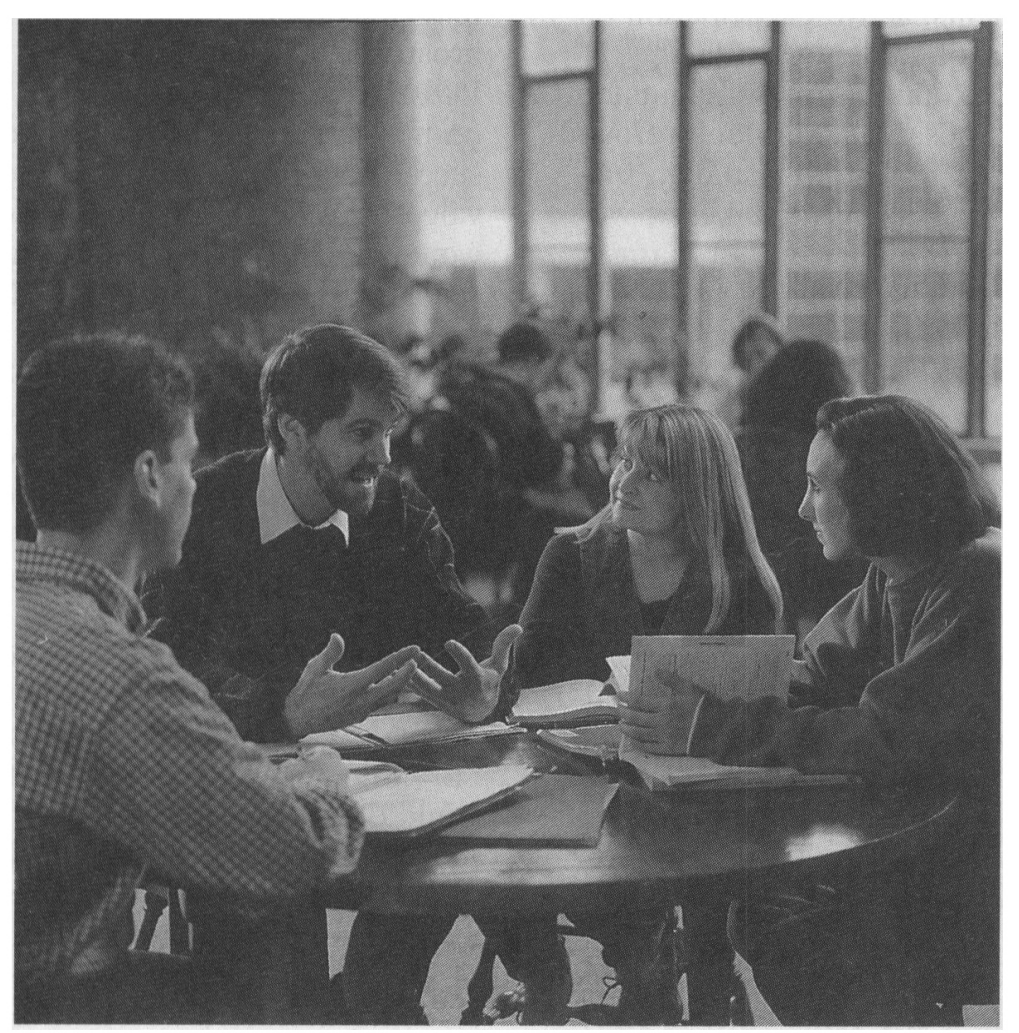

Photo courtesy of Drake University ates that raises many issues of individualism, community, and equality, and James Morone's The Democratic Wish (1998), which makes the case that Americans' penchant for individualism and their resulting distrust of strong government makes building effective government institutions difficult. This book also argues that a strand of egalitarianism, which often expresses itself in what Morone labels "the democratic wish," has helped in the past to counter that individualism. In the $1990 \mathrm{~s}$, the book concludes, redefining that wish will give Americans their best hope for building effective government. The book is a sweeping historical and political analysis, and is not one students taking an introductory American politics class would normally be expected to read and understand. Nonetheless, I assigned it at the end of the semester as a kind of synthesis of the themes we had explored. Since I knew that the students would have discussed these ideas in my class and would also have read Tocqueville and Bellah in their FYS, I had the confidence to take a chance on assigning this more difficult reading.

Throughout the semester, I tried to focus in-class discussions and out-of-class assignments on the issue of whether government can serve as an instrument of community and, if it can or should, how well it did so. For example, the students had to write three essays on, respectively, television's ability to influence citizens and policymakers, how well Congress functioned as an instrument of people's political will, and whether a stronger government could better foster community values in America. The first dealt with television and its effect on our system. For this paper, the students read the Mongerson book-a critique of the power the press has developed-watched the news, and critiqued the press and the book. I asked them to pay special atten- 
tion to whether the press generally acts in the interests of community builders.

The second paper required students to assess how well Congress works. They drew on the case studies in the Dewhirst book to describe how well Congress represented the wishes of American citizens and to argue whether imposing term limits would improve or hinder efforts to make congresspeople more accountable to voters.

For the final paper, I asked students to employ the framework of Morone's analysis to synthesize much of the material from both my class and their FYS. I asked them to critique Morone and discuss whether, in light of his argument, creating a stronger government could lead to the development of a stronger sense of community among Americans. I specifically asked them to prepare their response with reference to course readings and discussions from POLS001 and their FYS.

In addition to writing individual essays, I had the students do a series of group projects. At the beginning of the semester, I randomly assigned students to six-member groups that outside of class to complete four assignments. The group assignments serve two purposes. First, the groups get the students into the habit of meeting outside of class to discuss course material. Second, and most importantly, working in groups teaches practical political lessons.

One of the things I want my students in POLS001 to understand is that a political system can only function when people work together. I can easily formulate a balanced federal budget I find acceptable. I will find it much more difficult to convince a few hundred (or a few hundred million) people that I have formulated a good balanced budget. ${ }^{4}$ Group work illustrates forcefully the difficulty and necessity of building

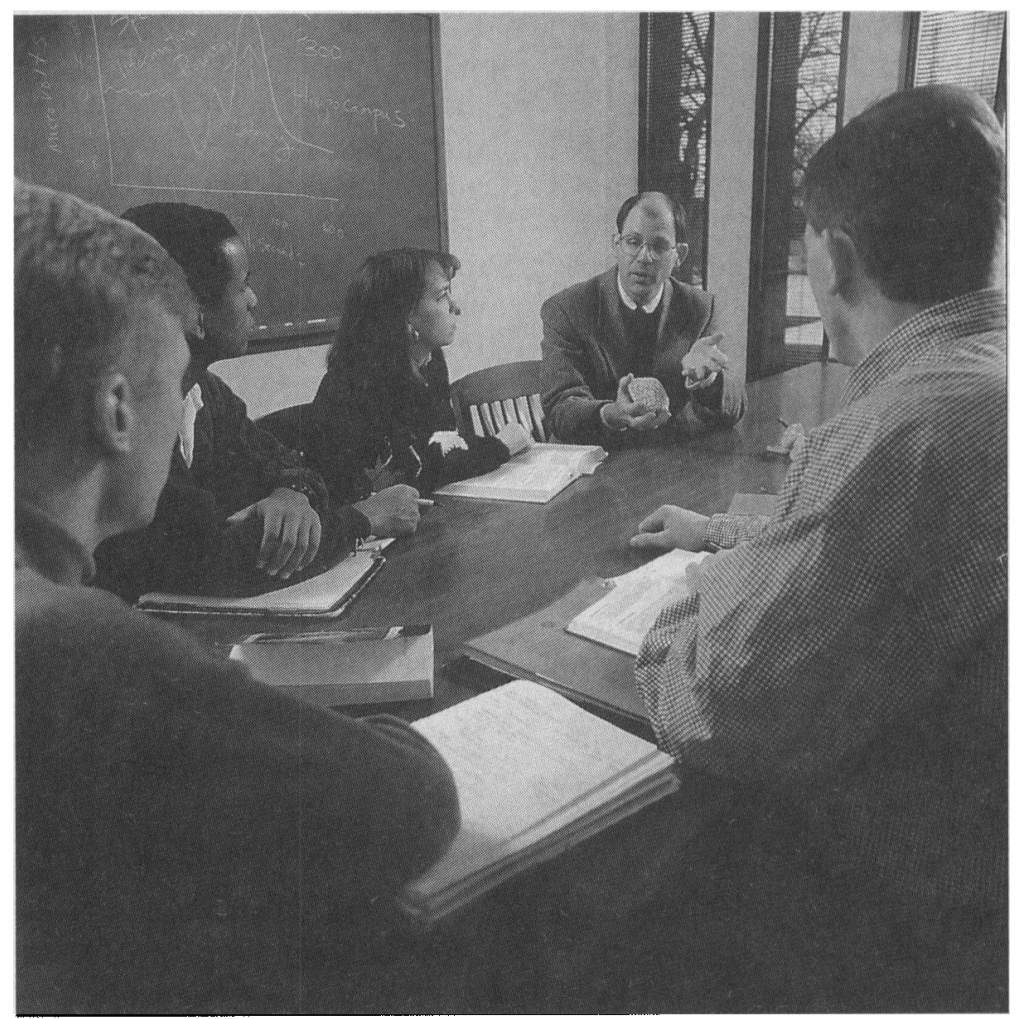

Photo courtesy of Drake University

political consensus, reinforcing the central theme of community.

To encourage students to be active members of their groups, I require each student to hand in an evaluation of their group's effort on each project, asking them to single out people who did more or less than their fair share of the work, however the group defines that. Students hate free riders, so I find they are brutally honest in assessing their peers' efforts. I also make students a deal regarding grades. As long as they participate actively within their groups, their overall group grades cannot lower their grades for the class. Thus, the " $A$ " student who is in a " $B$ " group will not suffer. If factoring in their group's grade will raise their individual grade, that is fine, but a low group grade will not lower the grade of an otherwise good student. Of course, if students are not helping their group, a low group grade can hurt them!

As I did with the essays, I designed the four group assignments so they would encourage students to reflect on themes of community and individualism. For the first, I asked students to look at the Constitution. They read and discussed the Constitution and Federalist 10 and 51 both in class and in their groups, and recommended any changes they would make to the Constitution. In particular, I asked them to address Hudson's critique of the separation of powers as a structure that hindered majorities (i.e., the community) from exercising proper power, but did not limit them to this topic.

The second group project dealt with campaign finance reform. While approaching the subject as a struggle among proponents of political equality-."All votes should be the same"-and individual rights"It's my money. It's free speech"students examined the McCainFeingold bill on campaign finance reform, portions of the Hudson book and the Levine reader, and a number of web sites with information and debate on the issue (e.g., Policy.com and the Center for Re- 
sponsive Politics' Open Secrets site [www.opensecrets.org/home.asp]). I asked students to come to some consensus, if possible, about how to balance the desire for equality in access with the rights of people and groups to free use of their resources.

For the third group assignment, students had to consider whether the U.S. Supreme Court balanced issues of rights and democracy. I asked them to explore the issue of the Court's ability to overturn laws passed by democratically elected bodies in order to protect individual rights. I asked them to address these questions with reference to decisions in the area of privacy and abortion while trying to set aside their personal views on abortion and looking at the broader issue of how the Court can (or should) decide such questions.

Finally, with the last group assignment, I tried to tie some of these themes together more broadly. I had student's read Robert Putnam's "Bowling Alone" (1995) and, pointed them to the Electronic Policy Network web site (http://epn.org/ ideacentral/politics), where they could read entries in a debate over Putnam's argument and examine issues raised by efforts at building community in America. I asked student's to consider whether they felt Americans needed to do more to build community and, if so, what citizen's could do, or if they felt there were other ways to improve our democracy, however the group might define such improvement. If the group thought Americans needed to do something to make things better (and all the groups did, though how much varied greatly), I asked them to pick two of the seven suggestions Hudson offered in his final chapter for improving American democracy and argue why these two goals should receive priority. The seven suggestions that Hudson offered are reforming institutions, building a communitarian movement, building grassroots movements, promoting democratic deliberation, rebuilding political parties and labor unions, revitalizing America's welfare state, and dismantling the war economy. He does not prioritize them, but I required students to do so. Government exists, after all, at least in part, to allow citizens to pick priorities. This assignment turned out better than I could have hoped, as all seven of the suggestions were recommended by at least one group. This allowed for a good class discussion of the difficulty of reaching consensus in a diverse nation even when there is agreement over basic principles and how such difficulties may hinder efforts to build a "national community."

\section{Results of the Community Experiment}

The learning community definitely fostered development of a group identity and development of a better understanding of the themes addressed in the courses. Students benefited from living on a common hall. Although initially leery of what living on a "smart hall" might imply-almost all community members were honors students - the students ended the semester praising the arrangement. By the end of the semester, students, when asked where they lived, would not answer with the building or the floor. They would simply say they lived in the learning community. It had become a part of their identity. This identity was so strong, in fact, that most of them requested to live together again on a common floor the following year, and the student life office agreed to keep them together. The first group's testimonials to the benefits of community living aided the recruiting of subsequent students immensely.

As hoped, the "town meetings" students held to discuss their courses and their money taught students quite useful lessons about making a democracy work. They found it necessary to create committees to get things done. They had to choose among more good ideas than they had the resources to realize and, thus, learned the importance of compromising and picking priorities. In short, students got a crash course in government formation and operation. Unexpectedly, the meetings became an example I could point to as we discussed various aspects of the American political system. Among the results of the meetings were a request that the FYS instructors meet with the students of the "other" class and that some of the group's money be used to fund a film series.

Discussions with colleagues at Drake about this community generally include questions about dealing with practical community issues. A favorite question is, "What do you do if the people in the community do not all get along?" We had a real advantage in dealing with this difficulty since the substantive topic to be addressed by members of our community was how to build community. Any experience, positive or negative, was a learning experience that could shed light on the issues students had to address. As it turned out, our students did, by and large, get along well together. If they had not, the conflicts that arose could have been used as lessons to illustrate how a community often has difficulties achieving all its members want to accomplish.

But did being part of this learning community really help students do better in the introductory American politics class? Yes, although it is important note that some of the advantages students enjoyed had nothing to do with their being members of a learning community. The class was smaller than usual, and was made up predominately of honors students. Even those who were not honors students wanted to be community members; there were no students in the class just to fulfill a general education requirement or because they needed one more course and this class met at the right time. This was a "dream class" for my students and me. The students were more engaged with the material than a normal POLS001 class. They asked more questions, made more comments, did better on the exams, and wrote better papers than typical POLS001 students. But some of that would have been true if I would have had those 36 students in the class without it being a part of the learning community. All that acknowledged, I believe being part of a learning community helped students learn in four ways. First, the 
students developed a common vocabulary to deal with the issues and problems raised in POLS001 that was explicitly reinforced outside my classroom. The discussions they had in their FYS sections helped them better refine that vocabulary and articulate the common principles that underlay both classes. They talked about individualism and equality in terms of government, but also in terms of everyday life. When they discussed issues such as the growth of the suburbs in the seminar, they were able to make connections to processes and issues they had covered in my class. Students had the opportunity to explore how the kinds of lives people live affect their political preferences and priorities, and how the political choices people make shape the kinds of communities they develop. Students could also talk about how America's political system promotes equality and think about how things might have improved or worsened since the Jacksonian era or how the meaning of equality itself had evolved. They were able to see more clearly the relationships between government, politics, and everyday life.

Second, because the students were all reading and discussing the same books in their FYS sections, I was able to draw upon those materials in my class as well. As noted above, some of my assignments, particularly the paper on the Morone book, required students to draw on their FYS materials. I could reference Tocqueville or Bellah in my class, knowing students had just read their books and discussed them in another class. Every classroom teacher has had the experience of making reference to some nonreading list material and expecting that most of the students would be minimally aware of it only to look out to a sea of blank faces. When I introduced the topic of interest groups' influence within the political system by talking about volunteer organizations and citizen participation having been a visible part of American culture since at least the Jacksonian period, I did not get blank faces. My colleagues teaching the FYS sections also quickly learned the value of being able to make such connections as well. They noted that class discussions and papers in their class often drew on the readings and material discussed in POLS001, particularly Federalist 10 and the Hudson and Morone books.

Many of the students reported forgetting which of the readings were assigned for which class.

Teachers often want students to recognize that the boundaries between different classes are arbitrary and to draw on material from other classes. But, since teachers rarely know exactly what other classes students have had or are taking, and since those classes differ from student to student, it is often hard to lead students to break down the perceived barriers separating courses in productive ways. The learning community structure allowed the FYS instructors and me to encourage the students to bridge the gaps that separate classes often create.

Third, as I briefly mentioned above, the students learned more about politics and our political system than they otherwise might have because they were required to "govern" themselves as a group. The town meetings, their discussions of how to allocate the money they had, and their experiences trying to organize a film series and a year-end dinner (which they ended up canceling because of a lack of time and interest), taught them important lessons in how difficult it is to keep a community going, even given the many advantages that a small community enjoys over a political community the size of the United States. And that, I think, gave them a much deeper appreciation of the difficulty of government. Simple solutions to problems did not seem quite as alluring as they had previously. Over the course of the semester, students developed a clearer and firmer understanding of the difficulties of governing a large, diverse nation, and a good sense of how the American concern with values of individuality and democracy create both benefits and tension for a political system, Relating these practical experiences to our readings and discussions of politics in America was very enlightening for them. They became, I think, more forgiving of Congress, interest groups, and political parties than most introductory American politics students end up, but perhaps less forgiving of their fellow citizens' unwillingness to engage the political system.

A final pedagogical benefit of the learning community was that the group projects worked better. Part of this resulted from improved logistics. Since just about all of the students lived on the same hall, it was much easier for groups to arrange times to meet. More than that, students had a greater familiarity with each other. Groups typically take a couple of assignments to sort themselves out and find patterns of work that they find effective. The groups in this class were working well together even during the first assignment.

\section{Improving the Community}

Since first organizing the learning community, my colleagues and I made two changes to improve the experience. First, we coordinated the classes even more fully so we could draw even more on the connections that exist between them.

Second, I added a reading that is more supportive of the current political structure as a successful attempt at building political community. While some of the chapters in the Levine reader take such a perspective, the students benefitted from reading explicit arguments that our system does strike an effective balance between individualism and equality and does create a reasonably strong and effective political community. The collection of essays by Alan Brinkley, Nelson Polsby, and Kathleen Sullivan titled New Federalist Papers: Essays in Defense of the Constitution (1997) filled this void, and was short enough so it did not overwhelm the students with too much material. I kept the basic structure of the other readings, though I used a different book on the media, Timothy Cook's Governing with the News (1998), which has a nice historical perspective on the subject.

In addition, my colleagues and I are now considering the issue of expansion. One of the questions asked 
by many students as they began choosing their classes for the spring was, "What do we do now that can continue and build on this wonderful experience we are having?" Unfortunately, no one had a good answer to that question. Some students have suggested making the community a year-long experience. The idea is intriguing, but many questions need to be answered before any such expansion could take place: Would students sign on for such an experience? Could students drop out of the community after the first semester, or join for the first time in the second semester? What would the courses in the second semester cluster be? And how many resources should be allocated to provide special attention to a group of, at most, 40 students?

In conclusion, I want to draw attention to two things I have learned from teaching in this community that I think are useful for any section of introductory American politics. Most readers will not have the luxury of embedding their course in a learning community, but this does not mean that some of the commu- nity concepts should not inform the teaching of "regular" courses.

First, this class reinforced to me the usefulness of group projects. Approached reflectively, group projects can be used to help students develop an understanding of the way a political system tries to come to agreement over difficult issues. I now spend more time discussing this motivation for requiring students to work in groups, and initiate discussions of group dynamics when looking at interest groups or Congress. In the future, I plan to focus even more on the process of group activity.

Lastly, I found that the explicit focus on themes of individualism and equality helped students conceptualize and make meaningful connections among the various topics addressed in my introductory American politics class. Examining federal-state relations, the role of the media, political parties, interest groups, elections, Congress, the presidency, and the courts with an eye toward how each encourages or discourages individuality or community gives students a useful frame- work for pursuing specific topics. I would not argue this is the only possible theme that one could use in this way, but I found it very useful. Looking at government as an attempt to pool individually held resources together for the benefit of the entire community without taking away too much of the freedom people want helped students understand the potentialities and limitations of government by giving rise to questions like: Do political parties help forge compromise or do they divide citizens and legislators? How can members of Congress pass bills when they have to represent such a diverse nation? Does mass media draw people together or drive them apart? Can the president represent the entire nation while at the same time pushing specific policies that some people will not support? Is the Supreme Court protecting individual rights or thwarting democratic majorities? For the next few years at least, such questions will provide the central focus in all my sections of POLS001, both those taught within a learning community and those that are not.

\section{Notes}

1. A good general discussion of reform efforts in undergraduate education appears in Astin (1993). A comprehensive set of recommendations for designing effective reform programs can be found in a report by The Boyer Commission on Educating Under- graduates in the Research University titled Reinventing Undergraduate Education (http:// notes.cc.sunysb.edu/Pres/boyer.nsf).

2. For a closer look at learning communities, see Gabelnick et al. (1990).

3 . For some recent descriptions of other successful learning communities, see Levine and Tompkins (1996), Masterson (1998), and Shapiro and Levine (1999).

4. In the days of the deficit, creating a balanced budget was one of my favorite group assignments.

\section{References}

Astin, Alexander. 1993. What Matters in College? Four Critical Years Revisited. San Francisco: Jossey-Bass.

Bellah, Robert, et al. 1985. Habits of the Heart Individualism and Commitment in American Life. New York: Harper and Row.

Brinkley, Alan, Nelson Polsby, and Kathleen Sullivan. 1997. New Federalist Papers: Essays in Defense of the Constitution. New York: W.W. Norton and Twentieth Century Fund.

Cook, Timothy. 1998. Governing with the News: The Media as a Political Institution. Chicago: University of Chicago Press.

Dewhirst, Robert. 1997. Rites of Passage: Congress Makes Laws. Upper Saddle River, NJ: Prentice-Hall.

Gabelnick, Faith, Jean MacGregor, Roberta Matthews, and Barbara Leigh Smith, eds. 1990. Learning Communities: Building
Connections among Disciplines, Students, and Faculty. San Francisco: Jossey-Bass.

Hudson, William. 1998. American Democracy in Peril: Seven Challenges to America's Future. 2nd ed. Chatham, NJ: Chatham House.

Kunstler, James. 1996. Home from Nowhere: Remaking Our Everyday World for the 21st Century. New York: Simon \& Schuster.

Levine, Herbert, ed. 1998. Point-Counterpoint. 6th ed. New York: St Martin's Press

Levine, Jodi, and Daniel Tompkins. 1996. "Making Learning Communities Work: Seven Lessons from Temple University." AAHE Bulletin 48(June): 3-6.

Masterson, John. 1998. "What Learning Communities Teach." AAHE Bulletin 50(April): 8-9.

Matthews, Roberta, Barbara Leigh Smith, Jean MacGregor, and Faith Gabelnick. 1996. "Learning Communities: A Struc- ture for Educational Coherence." Liberal Education 82(Summer): 4-9.

Mongerson, Paul. 1997. The Power Press: Its Impact on America and What You Can Do about It. Golden, CO: Fulcrum Publishing.

Morone, James. 1998. The Democratic Wish: Popular Participation and the Limits of American Government. Rev. ed. New Haven: Yale University Press.

Putnam, Robert. 1995. "Bowling Alone America's Declining Social Capital." Journal of Democracy 6(January): 65-78.

Shapiro, Nancy, and Jodi Levine. 1999. Creating Learning Communities: A Practical Guide to Winning Support, Organizing for Change and Implementing Programs. San Francisco: Jossey-Bass.

Tocqueville, Alexis de. 1990. Democracy in America. Vol. 2. New York: Random House/Vintage. 